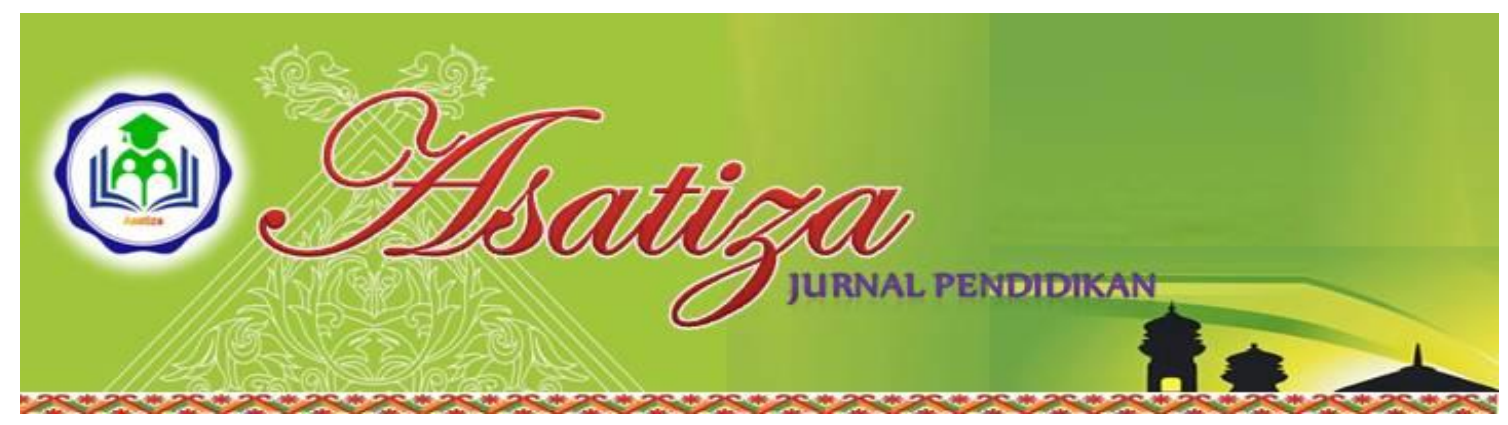

\title{
PELAKSANAAN METODE PEMBIASAAN DI PENDIDIKAN ANAK USIA DINI BINA GENERASI TEMBILAHAN KOTA
}

\author{
Khalifatul Ulya ${ }^{1}$ \\ ${ }^{1}$ STAI Auliaurrasyidin Tembilahan
}

\begin{abstract}
Abstrak
Penelitian ini bertujuan untuk mengetahui pelaksanaan metode pembiasaan ini dalam membiasakan unsur-unsur positif pada proses belajar mengajar Di Pendidikan Anak Usia Dini (PAUD) Bina Generasi Tembilahan Kota.

Adapun teknik pengumpulan data yang dilakukan oleh penulis dalam penelitian ini adalah menggunakan observasi, dan dokumentasi, dan hasilnya dianalisis dengan menggunakan rumus deskriptif analitik prosentase.

Dari analisis data yang dilakukan oleh penulis maka didapatkan hasil penelitian dari Berdasarkan hasil rekapitulasi hasil observasi Pelaksanaan Metode Pembiasaan Di Pendidikan Anak Usia Dini Bina Generasi Tembilahan Kota dikategorikan "baik" dengan prosentase $78.57 \%$ yang berada diinterval $61 \%-80 \%$.
\end{abstract}

Kata Kunci: Pelaksanaan,Metode, Pembiasaan

\section{A. PENDAHULUAN}

\section{Latar belakang}

Program pembelajaran belum dapat memberikan hasil yang memuaskan. Hal ini terlihat ketika proses pembelajaran berlangsung di dalam kelas, suasana nampak tidak menyenangkan dan membosankan. Guru juga kurang mampu membangkitkan motivasi murid dalam belajarnya. ${ }^{1}$

Keberhasilan guru dalam mengajar ditentukan oleh banyak faktor, antara lain metode mengajar yang digunakan guru dalam kelas maupun luar kelas. ${ }^{2}$ Dalam perkembangannya istilah pendidikan berarti bimbingan atau pertolongan yang diberikan secara sengaja terhadap anak didik oleh orang dewasa agar anak didik menjadi dewasa, dalam perkembangan selanjutnya, pendidikan berarti usaha yang dijalankan oleh seseorang atau sekelompok orang untuk mempengaruhi seseorang atau sekelompok orang agar menjadi dewasa atau mencapai tingkat hidup dan penghidupan yang lebih tinggi dalam arti mental. Dengan demikian pendidikan berarti, segala usaha orang dewasa dalam pergaulan dengan anakanak untuk memimpin perkembangan jasmani dan rohaninya kedewasaan.
${ }^{1}$ Arief S. Sadiman, Media Pendidikan, (Jakarta: Rajawali Pers, 2006), hlm.87.
${ }^{2}$ E. Mulyasa, Menjadi Guru Profesional, (Bandung: PT Remaja Rosdakarya, 2007), Hlm. 35 
Anak merupakan amanah Allah SWT. Yang harus dijaga dan dibina. Hati yang suci merupakan permata yang sangat mahal harganya. Ia membutuhkan pemeliharaan, penjagaan, kasih sayang, dan perhatian. Jika dibiasakan dengan kejahatan dan dibiarkan seperti makhluk hidup selain manusia, ia akan celaka dan binasa. Cara memeliharanya dengan pendidikan akhlak yang baik.

Menurut Armai Arief, metode pembiasaan adalah cara yang dapat dilakukan untuk membiasakan anak didik berpikir, bersikap, bertindak sesuai dengan tuntunan ajaran islam. ${ }^{3}$ Sebagaimana sabda Rasulullah:

"Telah menyampaikan kepada kami Adam, telah menyampaikan kepada kami Abi Zib'in dari AzZuhri dan Abi Salamah bin Abdirrahman dari Abu Hurairah r.a ia berkata:' Bersabda Rasulullah SAW.,'Setiap anak dilahirkan diatas fitrahnya maka kedua orang tuanyalah yang menjadikannya seorang Yahudi, Nasrani, atau Majusi." (H.R. Bukhari) ${ }^{4}$

Dari hadis ini dapat dipahami, begitu pentingnya peran orang tua dalam membentuk kepribadian anak pada masa yang akan datang. Di sini dapat dilihat bahwa betapa pentingnya pendidikan bagi anak-anak, dan jelas pula bahwa anak-anak harus mendapatkan pendidikan yang layak.

${ }^{3}$ Armai Arief, Pengantar Ilmu Dan Metodologi Pendidikan Islam, (Jakarta: ciputat Pres, 2002), hlm. 110.

${ }^{4}$ Dindin Jamaludin, Paradigma Pendidikan Dalam Islam, (Bandung: Pustaka Setia, 2013,) hlm. 37.

${ }^{5}$ Dindin Jamaludin, Paradigma Pendidikan Dalam Islam, (Bandung: PUSTAKA SETIA, 2013,) hlm. 40.
Apabila generasi penerus suatu bangsa bagus, masa depan bangsa pun akan bagus pula. Begitu juga sebaliknya, apabila generasi atau penerus bangsa rusak, suram juga masa depan bangsa tersebut.

Lembaga pendidikan menyentuh seluruh aspek yang bersinggung langsung dengan kebutuhan berkembang individu anak-anak, baik dari ilmu agama maupun ilmu umum agar mereka dapat hidup dan berkembang sesuai dengan ajaran agama Islam yang kaffah. ${ }^{5}$

Dikarenakan anak adalah merupakan aset yang tak ternilai harganya bagi orang tua, maka wajarlah bila orang tua selalu ekstra hati-hati dan was-was atau ingin memastikan bahwa si anak tumbuh dan berkembang secara baik. $^{6}$ Kita sebagai orang tua atau pendidik harus memberikan contoh nyata atau keteladanan yang baik pada anak-anak. Terutama di usia anak dua tahun keatas, biasanya sifat egoisentris muncul dalam dirinya. Dalam fase ini, anak akan mengalami ego diri yang tak dapat dibendung, selagi ia belum bisa melihat dari sudut pandang orang lain. ${ }^{7}$

Pembiasaan adalah salah satu alat pendidikan yang penting sekali, terutama bagi anak-anak yang masih kecil. Anak-anak kecil belum menginsafi apa yang dikatakan baik dan

${ }^{6}$ Agnes Tri Harjaningrum, Peranan Orang Tua Dan Praktisi Dalam Membentuk Tumbuh Kembang Anak Berbakat Melalui Pemahaman Teori Dan Tren Pendidikan, (Jakarta: PRENADA,2007), hlm.5.

${ }^{7}$ Ahmad Susanto, Perkembangan Anak Usia Dini, (Jakarta: KENCANA,2011), hlm.3. 
apa yang dikatakan buruk dalam arti susila. Juga anak kecil belum mempunyai kewajiban-kewajiban yang harus dikerjakan seperti orang dewasa, tetapi mereka sudah mempunyai hak seperti hak dipelihara, hak mendapat perlindungan, dan hak mendapat pendidikan. Anak kecil belum kuat ingatannya, ia cepat melupakan apa yang sudah dan baru terjadi. Perhatian mereka mudah beralih kepada hal-hal yang baru, yang lain, yang disukainya. Apalagi anak-anak yang baru lahir, hal itu semua belum ada sama sekali atau setidaknya, belum sempurna sama sekali.

Oleh karena itu, sebagai permulaan dan sebagai pangkal pendidikan, pembiasaan merupakan alat satusatunya. Sejak dilahirkan anak-anak harus dilatih dengan kebiasaankebiasaan dan perbuatan-perbuatan yang baik, seperti dimandikan dan ditidurkan pada waktu tertentu, diberi makan dengan teratur, dan sebagainya. Menurut Ramayulis, metode pembiasaan adalah cara untuk menciptakan suatu kebiasaan atau tingkah laku tertentu bagi anak didik. ${ }^{8}$

Pembiasaan yang baik penting artinya bagi pembentukan watak anakanak, dan juga akan terus berpengaruh kepada anak itu sampai hari tuanya. Menananmkan kebiasaan pada anakanak adalah sukar dan kadang-kadang memakan waktu yang lama. Akan tetapi, segala sesuatu yang telah menjadi kebiasaan sukar pula kita ubah.

${ }^{8}$ Ramayulis, Metodologi Pendidikan Agama Islam, (Jakarta: Kalam Mulia, 2005), hlm. 103.
Maka dari itu, lebih baik kita menjadikan anak-anak kita supaya mempunyai kebiasaan-kebiasaan yang baik dari pada terlanjur memiliki kebiasaan-kebiasaan yang tidak baik. ${ }^{9}$

Namun pada studi pendahuluan yang dilakukan oleh penulis di Pendidikan Anak Usia Dini, penulis menemukan beberapa gejala yang menurut penulis perlu dilakukan penelitian, diantaranya adalah, penulis menemukan beberapa anak yang membuang sampah tidak pada tempatnya.

Kemudian penulis menemukan beberapa anak yang tidak membaca do'a sebelum makan, padahal pada pendidikan anak usia dini do'a sebelum makan sudah dirh guru.

Metode pembiasaan ini perlu dilakukan oleh guru dalam rangka pembentukan karakter, untuk membiasakan peserta didik melakukan pilaku terpuji (akhlak mulia). ${ }^{10}$ rumusan masalah sebagai berikut: "Bagaimana Pelaksanaan Metode Pembiasaan Di Pendidikan Anak Usia Dini Tembilahan Kota?"

\section{Pengertian Metode Pembiasaan}

Secara etimologi, pembiasaan asal katanya adalah biasa. Dalam kamus Besar Bahasa Indonesia, biasa artinya lazim atau umum, seperti sedia kala, sudah merupakan hal yang tidak bisa dipisahkan dalam kehidupan seharihari. Jadi, pembiasaan artinya Proses membuat sesuatu menjadi biasa, 
sehingga menjadi kebiasaan. Untuk membentuk peserta didik agar memiliki akhlak terpuji, metode pembiasaan, merupakan metode yang efektif. Dengan metode pembiasaan ini, peserta didik diharapkan dapat membiasakan dirinya dengan prilaku mulia.

Sebelum anak berfikir logis dan memahami hal-hal yang abstrak, serta belum sanggup menentukan mana yang baik dan mana yang buruk, mana yang benar dan mana yang salah, maka contoh-contoh, latihan-latihan dan pembiasaan-pembiasaan mempunyai peranan yang sangat penting, dalam pembinaan pribadi anak, karena masa kanak-kanak adalah masa paling baik untuk menanamkan dasar-dasar pendidikan akhlak.

Al-Ghazali mengemukakan metode mendidik anak dengan memberi contoh, latihan dan pembiasaan kemudian nasehat dan anjuran sebagai alat pendidikan dalam rangka membina kepribadian anak sesuai dengan ajaran agama Islam. Membentuk kepribadian itu berlangsung secara berangsur-angsur dan berkembang sehingga merupakan proses menuju kesempurnaan. Dalam hal ini Al-Ghazali mengatakan:

"Apabila anak dibiasakan untuk mengamalkan segala sesuatu yang baik, diberi pendidikan kearah itu, pastilah ia akan tumbuh di atas kebaikan dan akibat positifnya ia akan selamat sentosa si dunia dan di akhirat. Kedua orang tuanya dan semua pendidik, pengajar, dan

\footnotetext{
${ }^{11}$ Hamdani Ihsan Dan Fuad Ihsan, Filsafat Pendidikan Islam, (Bandung: CV Pustaka Setia, 2001), Hlm.240-241.

${ }^{12}$ Muhibbin Syah, Psikologi Pendidikan Dengan Pendekatan Baru, (Bandung: PT Remaja Rosdakarya,2008), hlm.118.
}

pengasuhnya ikut $\begin{array}{r}\text { serta } \\ \text { memperoleh }\end{array}$
pahalanya. Sebaliknya, jika anak kecil sudah dibiasakan mengajarkan keburukan dan dibiarkan begitu saja tanpa dihiraukan pendidikan dan pengajarannya sebagaimana halnya orang yang memelihara binatang, maka akibatnya anak itupun akan celaka dan rusak binasa akhlaknya, sedangkan dosanya yang utama tentulah dipikulkan oleh orang (orang tua, pendidik) yang bertanggung jawab untuk memelihara dan mengasuhnya."11

Menurut Burghardt, kebiaasaan itu timbul karena proses penyusutan kecenderungan respon dengan menggunakan stimulasi yang berulangulang. Dalam proses belajar, pembiasaan juga meliputi pengurangan prilaku yang tidak diperlukan. Karena proses penyusutan atau pengurangan inilah, muncul suatu pola bertingkah laku baru yang relatif menetapdan otomatis. $^{12}$

Menurut Abdullah Nasih Ulwan, metode pembiasaan adalah cara atau upaya yang praktis dalam bentuk (pembinaan) dan persiapan. ${ }^{13}$ Menurut Ramayulis, metode pembiasaan adalah cara untuk menciptakan suatu kebiasaan atau langkah laku tertentu bagi anak didik. $^{14}$

Sebagai seorang teladan, Rasulullah SAW menggunakan metode pembiasaan dalam rangka untuk membiasakan dirinya agar selalu dalam

\footnotetext{
${ }^{13}$ Abdullah Nasih Ulwan, Pendidikan Anak Menurut Islam, (Bandung: Rosda Karya, 1992), Hlm. 60.

${ }^{14}$ Ramayulis, Metodologi Pendidikan Agama Islam, (Jakarta: Kalam Mulya, 2005), Hlm.103.
} 
kebaikan dan ibadah. ${ }^{15}$ Rasulullah mengajarkan akhlak dan menanamkan pola berpikir melalui kebiasaan yang dilakukan secara berulang-ulang. Sebab di antara cara mengajar yang terbaik adalah tingkah laku harus sesuai dengan ilmu dan hal itu dilakukan secara berulang-ulang di hadapan muridmurid, sehingga akhlak mulia dan prilaku luhur dapat disaksikan secara berulang-ulang. Jika contoh yang dibiasakan kepada murid-murid itu buruk, maka ia akan menjadi hukum dan kebiasaan jika dilakukan secara berulang-ulang, sehingga menjadi tradisi yang sulit untuk diubah. Rasulullah sendiri telah menyatakan hakekat ini dengan sabdanya, kebaikan adalah kebiasaan. Maka barang siapa yang ingin mengajarkan kebaikan, hendaknya dia menjadikan kebaikan itu sebagai kebiasaan yang dilakukan secara berulang-ulang di hadapan murid-muridnya. ${ }^{16}$

Menurut ahmad tafsir, metode pembiasaan ini sangat efektif untuk menguatkan hapalan-hapalan pada anak didik, dan untuk menanamkan sikap beragama dengan cara hapalan do'ado'a, dan ayat-ayat piihan. Dalam dunia psikologi, metode pembiasaan ini dikenal dengan teori operant conditioning yang membiasakan peserta didik untuk membiasakan prilaku terpuji, disiplin dan giat belajar, bekerja keras dan ikhlas, jujur dan tanggung jawab atas segala tugas yang telah dilakukan. Metode pembiasaan ini perlu dilakukan oleh guru dalam rangka pembentukan karakter, untuk membiasakan peserta didik melakukan perilaku terpuji (akhlak mulia).

Menurut Mulyasa Pendidikan dengan pembiasaan dapat dilaksanakan secara terprogram dalam pembelajaran atau dengan tidak terprogram dalam kegiatan sehari-hari. Kegiatan pembiasaan dalam pembelajaran secara terprogram dapat dilaksanakan dengan perencanaan khusus dalam kurun waktu tertentu. ${ }^{17}$

Pembiasaan adalah salah satu alat pendidikan yang penting sekali, terutama bagi anak-anak yang masih kecil. Anak-anak kecil belum menginsafi apa yang dikatakan baik yang dikatakan buruk dalam arti susila. Juga anak kecil belum mempunyai kewajiban-kewajiban yang harus dikerjakan seperti orang dewasa. Oleh karena itu, sebagai permulaan dan pangkal pendidikan, pembiasaan sebagai merupakan alat satu-satunya. Sejak dilahirkan anak-anak harus dilatih dengan kebiasaan-kebiasaan dan perbuatan-perbuatan yang baik.

Pembiasaan yang baik penting artinya bagi pembentukan watak anakanak, dan juga akan terus berpengaruh kepada anak itu sampai hari tuanya. Menanamkan kebiasaan pada anak-anak adalah sukar dan kadang-kadang memakan waktu yang lama. Akan tetapi, segala sesuatu yanng telah
${ }^{15}$ Samsul Nizar Dan Zainal Efendi Hasibuan, Hadis Tarbawi, (Jakarta: Kalam Mulia,2011), hlm.73.
${ }^{16}$ Muhammad fathi, Metode Nabi Dalam Mendidik Dan Mengajar, (jakarta: pustaka alkausar,2009), hlm.52-53.

${ }^{17}$ Heri Gunawan, Pendidikan Karakter, (Bandung: Alfabeta, 2014) hlm.94. 
menjadi kebiasaan sukar pula kita ubah. Maka dari itu, lebih baik kita menjaga anak-anak kita supaya mempunyai kebiasaan-kebiasaan yang baik dari pada terlanjur memiliki kebiasaankebiasaan yang tidak baik. ${ }^{18}$

Dalam kaitan pembentukan tingkah laku melalui pembiasaan yang dilakukan secara terus-menerus dalam kehidupan anak sehari-hari dimaksudkan untuk mempersiapkan anak sedini mungkin.

Ditinjau dari segi perkembangan anak, pembentukan tingkah laku melalui kebiasaan akan membantu anak bertumbuh dan berkembang secara seimbang. Artinya memberikan rasa puas pada diri sendiri dan dapat diterima oleh masyarakatnya. Memungkinkan terjadinya hubungan antara pribadi yang baik, saling percaya, saling tingkah laku hendaknya lebih banyak dinyatakan dalam perbuatan dan tidak dalam ucapan saja. ${ }^{19}$

Pendidikan sejak dini akan menanamkan kebiasaan dalam diri anak, yang akan mendukung kesadaran penuh jika anak tercapai tingkah balignya. Untuk itu, seorang guru atau orang tua harus tua yang diajarkan kepada seorang anak serta metode yang telah di tuntunkan oleh Rasulullah SAW. Beberapa tuntunan tersebut antara lain sebagai berikut:

a. Menanamkan Tauhid Dan Akidah Yang Benar Kepada Anak

Hal yang tidak dapat dipungkiri bahwa tauhid merupakan landasan

\footnotetext{
${ }^{18}$ Ngalim Purwanto, Ilmu Pendidikan Teoritis Dan Praktis,

(Bandung: Remaja Rosdakarya, 2007) hlm.177.
}

islam. Apabila seseorang benar tauhidnya, dia akan mendapatkan keselamatan di dunia dan di akhirat. Sebaliknya, tanpa tauhid, dia terjatuh dalam kesyirikan dan akan menemui kecelakaan didunia serta kekekalan diakhirat.

b. Mengajari Anak Untuk Melaksanakan Ibadah

Hendaknya sejak kecil putra-putri diajarkan beribadah dengan benar sesuai dengan tuntunan Rasulullah SAW. Mulai dengan tata cara bersuci, shalat, puasa, dan ibadah lainnya. Apabila mereka dapat menjaga ketertiban dalam shalat, ajak pula untuk mengadiri shalat berjamaah di masjid. Dengan melatih anak sejak dini, mereka terbiasa dengan ibadah-ibadah tersebut berguna untuk membiasakan anak taat kepada Allah SWT.

c. Mengajarkan Al-Qur'an, Hadis, Do'a dan Zikir yang Ringan Kepada Anak

Hal ini dapat dimulai dengan mengajarkan Al-Qur'an surat Al-fatihah dan surat-surat yang pendek serta do'a Tahiyat untuk shalat. Kemudian, menyediakan guru khusus untuk mengajari tajwid, menghafal Al-Qur'an dan hadis. Begitu pula dengan do'a dan zikir sehari-hari. Hendaknya anak mulai menghafalkannya, seperti do'a ketika makan, keluar masuk WC, dan lain-lain. d. Mendidik Anak dengan Berbagai Adab dan Akhlak yang Mulia.

Ajarilah anak dengan berbagai adab Islami, seperti makan dengan tangan

\footnotetext{
${ }^{19}$ Moeslichatoen, Metode Pengajaran Di Taman Kanak-Kanak, (Jakarta: Rineka Citra, 2004), hlm.7-8.
} 
kanan, mengucapkan basmalah sebelum makan, menjaga kebersihan, mengucap salam, dan lain-lain.

Kiranya tidak diragukan lagi bahwa keutamaan akhlak dan tingkah laku merupakan salah satu iman yang meresap ke dalam kehidupan keberagamaan anak. Ia akan terbiasa dengan akhlak yang mulia karena ia menyadari bahwa iman membentengi dirinya dari berbuat dosa dan kebiasaan jelek.

e. Melarang Anak Dari Berbagai Perbuatan Yang Diharamkan.

Hendaknya anak sedini mungkin diperingatkan dari beragam perbuatan yang tidak baik atau diharamkan, seperti merokok, judi, minum khamar, mencuri, mengambil hak orang lain, zalim, durhaka kepada orang tua, dan lainnya. ${ }^{20}$

Jika sejak masa kanak-kanak tumbuh dan berkembang dengan berpijak pada landasan iman kepada Allah dan terdidik untuk selalu takut, ingat, pasrah, meminta pertolongan dan berserah diri kepada Allah, ia akan memiliki kemampuan dan bekal pengetahuan didalam menerima setiap keutamaan dan kemuliyaan, disamping terbiasa dengan sikap akhlak mulia. Sebab benteng pertahanan religius yang berakar pada hati sanubarinya, kebiasaan mengingat Allah yang telah dihayati dalam dirinya, dan intropeksi diri yang telah menguasai seluruh pikiran dan perasaan, dapat memisahkan anak dari sifat-sifat jelek, kebiasaan dosa, dan tradisi-tradisi jahiliah yang merusak. Setiap kebaikan akan diterima menjadi salah satu kebiasaan dan kesenangan, dan kemuliaan akan menjadi akhlak dan sifat yang paling utama.

Para pendidik bertanggung jawab untuk mendidik anak-anaknya agar berprilaku benar, jujur, menghargai, mencintai, menolong dan menghargai orang lain, menjaga lidahnya dari perkataan kotor, menjauhkan diri dari perbuatan dosa, dan lain-lain. ${ }^{21}$ Dengan demikian, Al-Ghazali sangat menganjurkan untuk mendidik anak dan membina akhlaknya dengan latihanlatihan dan pembiasaan-pembiasaan yang sesuai dengan perkembangan jiwanya walaupun seakan-akan dipaksakan, agar anak dapat terhindar dari keteralanjuran yang menyesatkan. Pembiasaan dan latihan tersebut akan membentuk sikap tertentu pada anak, yang lambat laun sikap itu akan bertambah jelas dan kuat, sehingga tidak tergoyahkan lagi karena telah masuk bagian dari kepribadiannya.

Menurut Zakiah Derajat, pengalaman-pengalaman yang dilalui sejak kecil bahkan sejak dalam kandungan, merupakan unsur-unsur yang akan menjadi bagian dari kepribadian di kemudian hari.

Menurut Dr. Muhammad AlGhazali menguatkan pendapat tersebut dengan menyatakan bahwa suatu ajaran yang akan membuahkan hasil membutuhkan latihan-latihan pembiasaan yang panjang proses waktunya perhatian (dari pendidik) yang konstan. ${ }^{22}$

\footnotetext{
${ }^{22}$ Ibid. Hlm.241.
}

${ }^{20}$ Ibid, hlm. 60-61.

${ }^{21}$ Ibid, hlm.76-77 
Seseorang yang telah mempunyai kebiasaan tertentu akan dapat melaksanakannya dengan mudah dan senang hati. Bahkan, segala sesuatu yang telah menjadi kebiasaan dalam usia muda sulit untuk dirubah dan tetap berlangsung sampai hari tua. Untuk mengubahnya seringkali diperlukan terapi dan pengendalian diri yang serius.

Atas dasar ini, para ahli pendidikan senantiasa mengingatkan agar anakanak segera dibiasakan dengan sesuatu yang diharapkan menjadi kebiasaan yang baik sebelum terlanjur mempunyai kebiasaan lain yang berlawanan dengannya. Tindakan praktis mempunyai kedudukan penting dalam Islam. Islam dengan segala penjelasan menuntut manusia untuk mengarahkan tingkah laku, instink, bahkan hidupnya untuk merealisasi hukum- hukum ilahi secara praktis. Praktik ini akan sulit terlaksana manakala seseorang tidak terlatih dan terbiasa untuk melaksanakannya.

\section{Langkah-langkah pelaksanaan metode pembiasaan}

Adapun

langkah-langkah

pelaksanaan metode pembiasaan adalah sebagai berikut:

a. Melatih hingga benar-benar paham dan bisa melakukan tanpa kesulitan.

b. Mengingatkan anak yang lupa melakukan.

c. Apresiasi pada masing-masing anak secara pribadi.

${ }^{23}$ Zakiah darajat., ilmu jiwa agama.

${ }^{24}$ Muhibbin Syah, Psikologi Pendidikan Dengan Pendekatan Baru, (bandung: PT Remaja Rosdakarya,2008), hlm. 123-124 d. Hindarkan mencela pada anak. ${ }^{23}$

Belajar kebiasaan adalah proses pembentukan kebiasaan-kebiasaan baru atau perbaikan kebiasaan-kebiasaan yang telah ada. Belajar kebiasaan, selain menggunakan perintah, suri tauladan dan pengalaman khusus juga menggunakan hukuman dan ganjaran. Tujuannya agar siswa memperoleh sikap-sikap dan kebiasaan-kebiasaan perbuatan baru yang lebih tepat dan positif dalam arti selaras dengan kebutuhan ruang dan waktu (kontekstual). Selain itu, arti tepat dan positif di atas ialah selaras dengan norma dan tata nilai moral yang berlaku, baik yang bersifat religius maupun tradisional dan kultural. ${ }^{24}$

Syarat-Syarat Pembiasaan terdiri antara lain adalah: Mulailah pembiasaan itu sebelum terlambat, jadi sebelum anak itu mempunyai pembiasaan lain yang berlawanan dengan hal-hal yang akan dibiasakan, Pembiasaan itu hendaknya terus menerus (berulangulang) dijalankan secara teratur sehingga akhirnya menjadi suatu kebiasaan yang otomatis. Untuk itu, dibutuhkan pengawasan., Pendidikan hendaklah konsekuen, bersikap tegas dan tetap teguh terhadap pendiriannya yang telah diambilnya. Jangan memberi kesempatan pada anak untuk melanggar pembiasaan yang telah dibiasakan itu dan Pembiasaan yang mula-mulanya mekanistis itu harus makin menjadi pembiasaan yang disertai kata hati anak itu sendiri. ${ }^{25}$

\footnotetext{
${ }^{25}$ Ngalim Purwanto, Ilmu Pendidikan Teoritis Dan Praktis, (Bandung: Pt Remaja Rosdakarya,2007), hlm.178.
} 
Metode pembiasaan (habituation) ini berintikan pengalaman. Karena yang dibiasakan itu ialah sesuatu yang diamalkan. Dan inti kebiasaan adalah pengulangan. Pembiasaan menempat kan manusia sebagai sesuatu yang istimewa, yang dapat menghemat kekuatan, karena akan menjadi kebiasaan yang melekat dan spontan, agar kegiatan itu dapat dilakukan dalam setiap pekerjaan. ${ }^{26}$

Secara etimologi, pembiasaan asal katanya adalah biasa. Dalam Kamus Besar Bahasa Indonesia, biasa artinya lazim atau umum, seperti sedia kala, sudah merupakan hal yang tidak terpisahkan dari kehidupan sehari-hari. Dengan adanya prefiks "pe" dan sufiks "an" menunjukkan arti proses. Jadi pembiasaan artinya proses membuat sesuatu menjadi biasa, sehingga menjadi kebiasaan. Untuk membentuk peserta didik agar memiliki akhlak terpuji, metode pembiasaan (ta'widiyat), merupakan metode yang efektif. Dengan metode pembiasaan (ta'widiyat) ini, peserta didik diharapkan dapat membiasakan dirinya dengan prilaku mulia.

Rasulullah SAW menggunakan metode pembiasaan dalam rangka untuk membiasakan dirinya agar selalu pembiasaan dalam rangka untuk membiasakan dirinya agar selalu dalam kebaikan dan ibadah. Sebagaimana telah dikemukakan sebelumnya:

"Rasulullah SAW melaksanakan shalat sehingga bengkak kakinya.

${ }^{26}$ Heri Gunawan, Pendidikan Karakter Konsep Danimplementasi, (Bandung: Alfabeta, 2014), hlm.93.
Rasulullah berkata, bukankah aku sebaiknya menjadi hamba yang bersyukur. Rasullulah adalah orang yang paling banyak meaksanakan salat, dan menyukai ibadah yang dilaksanakan terus menerus meskipun kecil. Rasulullah selalu bernafas tiga kali ketika minum pada cangkir. Rasulullah selalu puasa pada hari senin dan kamis, dan tidak puasa pada hari raya Idul Fitri, biasa melakukan shalat lima waktu sehari, terbiasa tepat waktu dan istiqomah, menjadi imam di masjid, Nabi juga mengaji Al-Qur'an setiap hari." ${ }^{27}$

Kegiatan pembiasaan dalam pembelajaran secara terprogram dapat dilaksanakan dengan perencanaan khusus dalam kurun waktu tertentu, untuk mengembangkan pribadi peserta didik secara individual, kelompok dan klasikal sebagai berikut:

a. Biasakan peserta didik untuk bertanya dalam setiap proses pembelajaran.

b. Biasakan peserta didik untuk belajar kelompok (cooperative learning) untuk menciptakan masyarakat belajar.

c. Biasakanlah oleh guru untuk selalu menjadi model dalam setiap pembelajaran.

d. Biasakan melakukan refleksi dalam setiap akhir pembelajaran.

e. Biasakan melakukan penilaian yang sebenarnya, adil dan transparan dengan berbagai cara.

${ }^{27}$ Samsul Nizar Dan Zainal Efendi Hasibuan, Hadis Tarbawi Membangun Kerangka Pendidikan Ideal Perspektif Rasulullah, (Jakarta: Kalam Mulia, 2011), hlm.73-75. 
f. Biasakan peserta didik untuk bekerja sama (team work) dan saling menujang satu sama lain.

g. Biasakanlah untuk belajar dengan menggunakan berbagai sumber belajar.

h. Biasakan untuk bekerja sama dan memberikan laporan kepada kedua orang tua peserta didik terhadap perkembangan prilakunya.

i. Biasakan peserta didik untuk tidak mencari kambing hitam dalam memutuskan masalah. ${ }^{28}$

Sehubungan itu tepatlah pesan Rasulullah kepada kita agar melatih atau membiasakan anak untuk melaksanakan sholat ketika mereka barusia tujuh tahun dan memukulnya (tanpa cedera/bekas) ketika mereka berumur sepuluh tahun atau lebih apabila mereka tak mengerjakannya. Dalam pelaksanaan metode ini diperlukan pengertian, kesabaran, dan ketelatenan orang tua, pendidik dan da'i terhadap anak atau peserta didiknya. $^{29}$

Latihan-latihan keagamaan yang menyangkut ibadah seperti sembahyang, do'a, membaca AlQur'an, (atau menghafal surah-surah pendek), sembahyang berjama'ah di sekolah, masjid atau langgar, harus dibiasakan sejak kecil, sehingga lama kelamaan akan tumbuh rasa senang melakukan ibadah tersebut. Dia dibiasakan sedemikian rupa, sehingga dengan sendirinya ia akan terdorong melakukannya, tanpa suruhan dari luar, tapi dorongan dari dalam. Ingat priinsip

\section{B. METODOLOGI}

Subjek penelitian ini adalah seluruh guru Di Pendidikan Anak Usia Dini Bina Generasi Tembilahan Kota.Objek dalam penelitian ini adalah pelaksanan Metode Pembiasaan Di Pendidikan Anak Usia Dini Bina Generasi Tembilahan Kota Populasi adalah wilayah generalisasi yang terdiri atas: obyek dan subyek yang mempunyai kualitas dan karakteristik tertentu yang ditetapkan oleh peneliti untuk dipelajari dan kemudian ditarik kesimpulan. ${ }^{30}$

Adapun populasi dalam penelitian ini adalah guru yang berjumlah 5 orang dan peserta didik kelas (A, B, C) berjumlah 35 peserta didik Di Pendidikan Anak Usia Dini Tembilahan Kota.

Teknik pengumpulan data yang penulis gunakan dalam penelitan ini adalah: Observasi, dan dokumentasi. Data yang sudah terkumpul, penulis kualifikasikan ke dalam bentuk angkaangka. Sehingga data tersebut bersifat kuantitatif. Untuk selanjutnya dianalisis dan interpretasikan secara deskiptif. Pengalihan data ke dalam bentuk kuantitatif.

${ }^{30}$ Sugiono, Metode Penelitian Kuantitatif Kualitatif Dan R\&D, (Bandung: Alfabeta, 1988), hlm.80.
Dan Implementasi, (Bandung: Alfabeta, 2014), hlm.94-95.

${ }^{29}$ Heri Jauhari Muchtar, Fikih Pendidikan, (Bandung: PT Remaja Rosdakarya,2008), hlm. 19. 


\section{PEMBAHASAN}

\section{Penyajian Data Hasil Observasi}

Data yang diperoleh melalui observasi yang dilakukan peneliti terhadap responden. Hasil observasi tentang penelitian ini dapat dilihat pada tabel sebagai berikut:

\begin{tabular}{|c|c|c|c|c|c|}
\hline \multirow{3}{*}{ No } & \multirow{3}{*}{ Aspek Yang Diteliti } & \multicolumn{4}{|c|}{ OPTION } \\
\hline & & \multicolumn{2}{|c|}{$\mathbf{Y a}$} & \multicolumn{2}{|c|}{ Tidak } \\
\hline & & $\mathbf{F}$ & $\%$ & $\mathbf{F}$ & $\%$ \\
\hline 1 & $\begin{array}{l}\text { Pendidik } \\
\text { membiasakan anak } \\
\text { mengucap salam } \\
\text { setiap masuk } \\
\text { sekolah }\end{array}$ & 21 & 100 & 0 & 0 \\
\hline 2 & $\begin{array}{l}\text { Pendidik } \\
\text { membiasakan anak } \\
\text { membaca Basmallah } \\
\text { setiap ingin } \\
\text { melakukan kegiatan }\end{array}$ & 14 & $\begin{array}{c}66.6 \\
7\end{array}$ & 7 & $\begin{array}{l}33 . \\
33\end{array}$ \\
\hline 3 & $\begin{array}{l}\text { Pendidik } \\
\text { membiasakan anak } \\
\text { membaca do'a setiap } \\
\text { akan melakukan } \\
\text { kegiatan }\end{array}$ & 19 & $\begin{array}{c}90.4 \\
8\end{array}$ & 2 & $\begin{array}{c}9.5 \\
2\end{array}$ \\
\hline 4 & $\begin{array}{l}\text { Pendidik dapat } \\
\text { melatih anak } \\
\text { membaca Al-Qur'an }\end{array}$ & 17 & $\begin{array}{c}80,9 \\
5\end{array}$ & 4 & $\begin{array}{l}19 \\
05\end{array}$ \\
\hline 5 & $\begin{array}{l}\text { Pendidik } \\
\text { membiasakan anak } \\
\text { melaksanakan sholat } \\
\text { dhuha di sekolah }\end{array}$ & 0 & 0 & $\begin{array}{l}2 \\
1\end{array}$ & $\begin{array}{c}10 \\
0\end{array}$ \\
\hline 6 & $\begin{array}{l}\text { Pendidik } \\
\text { membiasakan anak } \\
\text { melafalkan surah- } \\
\text { surah pendek }\end{array}$ & 9 & $\begin{array}{c}42.8 \\
6\end{array}$ & $\begin{array}{l}1 \\
2\end{array}$ & $\begin{array}{r}57 . \\
14\end{array}$ \\
\hline 7 & $\begin{array}{l}\text { Pendidik } \\
\text { membiasakan anak } \\
\text { berbicara dengan } \\
\text { baik dan sopan }\end{array}$ & 20 & $\begin{array}{c}95.2 \\
4\end{array}$ & 1 & $\begin{array}{c}4,7 \\
6\end{array}$ \\
\hline 8 & $\begin{array}{l}\text { Pendidikmembiasak } \\
\text { an anak menjaga } \\
\text { kebersihan }\end{array}$ & 20 & $\begin{array}{c}95.2 \\
4\end{array}$ & 1 & $\begin{array}{c}4,7 \\
6\end{array}$ \\
\hline 9 & $\begin{array}{l}\text { Pendidik } \\
\text { membiasakan anak } \\
\text { hormat kepada } \\
\text { orangtua }\end{array}$ & 21 & 100 & 0 & 0 \\
\hline 10 & $\begin{array}{l}\text { Pendidikmembiasak } \\
\text { an anak bertingkah } \\
\text { laku yang baik }\end{array}$ & 21 & 100 & 0 & 0 \\
\hline & Jum & $\begin{array}{c}16 \\
5\end{array}$ & $\begin{array}{c}78.5 \\
7\end{array}$ & $\begin{array}{l}4 \\
5\end{array}$ & $\begin{array}{r}21 \\
43\end{array}$ \\
\hline
\end{tabular}

Pada tabel di atas adalah hasil rekapitulasi akhir observasi dari Guru. Dimana Pelaksanaan Metode Pembiasaan Di Pendidikan Anak Usia Dini Bina Generasi Tembilahan Kota dengan jumlah "YA" sebanyak 165 dengan persentase $78.57 \%$ sedangkan jumlah yang menjawab "TIDAK" sebanyak 45 dengan persentase $21.43 \%$ dari 10 indikator penelitian yang diambil dari metode pembiasaan. Adapun perhitungan pelaksanaan metode pembiasaan di Pendidikan Anak Usia Dini Bina Generasi Tembilahan Kotaadalahdenganmenggunakanrumus: $P=\frac{F}{N} x 100 \%$

$$
\begin{aligned}
& \text { Keterangan: } \\
& \mathrm{P}=\text { Prosentase } \\
& \mathrm{F}=\text { Frekunsi } \\
& \mathrm{N}=\text { Jumlah responden }
\end{aligned}
$$

Untuk menentukan nilai $\mathrm{F}$ dengan cara memberikan bobot pada jawaban hasil observasi. Untuk jawaban "YA" dengan nilai bobot 1 , sedangkan jawaban "TIDAK" dengan bobot 0 .

Jadi untuk menentukan $\mathrm{F}$ dengan cara:

$$
\begin{aligned}
& \text { 1. Nilai Ya } 165 \times 1=165 \\
& \text { 2. Nilai Tidak } 45 \times 0=0
\end{aligned}
$$

Kemudian kedua hasil tersebut dijumlahkan sehingga diperoleh nilai $\mathrm{F}$ $=165+0=165$

Sedangkan untuk mencari $\mathrm{N}$ adalah dengan cara:

$N=10 \times 3 \times 7 \times 1$

$N=210$

Setelah di tentukan nilai $\mathrm{F}$ dan $\mathrm{N}$ untuk menentukan prosentase terakhir adalah

$P=\frac{F}{N} \times 100 \%$ 


$$
\begin{aligned}
P & =\frac{165}{210} x 100 \% \\
P & =78.57 \%
\end{aligned}
$$

\section{E. KESIMPULAN}

Berdasarkan hasil rekapitulasi hasil observasi Pelaksanaan Metode Pembiasaan Di Pendidikan Anak Usia Dini Bina Generasi Tembilahan Kota dikategorikan "baik" dengan prosentase $78.57 \%$ yang berada diinterval 61\%-80\%.

\section{REFERENSI}

Abdullah Nasih Ulwan, Pendidikan Anak Menurut Islam, (Bandung: Rosda Karya, 1992)

Agnes Tri Harjaningrum, Peranan Orang

Tua Dan Praktisi Dalam Membentuk Tumbuh Kembang Anak Berbakat Melalui Pemahaman Teori Dan Tren Pendidikan, (Jakarta: Prenada,2007)

Ahmad Susanto, Perkembangan Anak Usia Dini, (Jakarta: KENCANA,2011)

Arief S. Sadiman, Media Pendidikan, (Jakarta: Rajawali Pers, 2006)

Armai Arief, Pengantar Ilmu Dan Metodologi Pendidikan Islam, (Jakarta: ciputat Pres, 2002)

Dindin Jamaludin, Paradigma Pendidikan Dalam Islam, (Bandung: Pustaka Setia, 2013,)

E. Mulyasa, Menjadi Guru Profesional, (Bandung: PT Remaja Rosdakarya, 2007)

Hamdani Ihsan Dan Fuad Ihsan, Filsafat Pendidikan Islam, (Bandung: CV Pustaka Setia, 2001)

Heri Gunawan, Pendidikan Karakter Konsep Dan Implementasi, (Bandung: Alfabeta, 2014)

Heri Jauhari Muchtar, Fikih Pendidikan, (Bandung: PT Remaja Rosdakarya, 2008)
Moeslichatoen, Metode Pengajaran Di

Taman Kanak-Kanak, (Jakarta: Rineka Citra, 2004)

Moh. Uzer Usman, Menjadi Guru Profesional, (Bandung: Remaja Rosdakarya, 2008)

Muhammad Ali, Guru Dalam Proses Belajar Mengajar, (Bandung: Sinar Baru Algensindo, 2002)

Muhammad fathi, Metode Nabi Dalam Mendidik Dan Mengajar, (jakarta: pustaka al-kausar,2009)

Muhibbin Syah, Psikologi Pendidikan Dengan Pendekatan Baru, (Bandung: PT Remaja Rosdakarya,2008)

Ngalim Purwanto, Ilmu Pendidikan Teoritis Dan Praktis, (Bandung: Pt Remaja Rosdakarya,2007)

Ramayulis, Metodologi Pendidikan Agama Islam, (Jakarta: Kalam Mulia, 2005)

Samsul Nizar Dan Zainal Efendi Hasibuan, Hadis Tarbawi Membangun Kerangka Pendidikan Ideal Perspektif Rasulullah, (Jakarta: Kalam Mulia, 2011)

Sugiono, Metode Penelitian Kuantitatif Kualitatif Dan $R \& D, \quad$ (Bandung: Alfabeta, 1988)

Zakiah Darajat, Ilmu Jiwa Agama, (Jakarta: PT. Bulan Bintang, 2005) 